\title{
KÖZÉRDEKÜ ADAT-E A PIACI BEVÉTEL FELHASZNÁLÁSÁRA VONATKOZÓ INFORMÁCIÓ? - NYILVÁNOSSÁG A KÖZTULAJDONBAN ÁLLÓ GAZDASÁGI TÁRSASÁGOK VONATKOZÁSÁBAN *
}

\author{
Révész Balázs - Buzás Péter ${ }^{1}$
}

Az állami és önkormányzati tulajdonban álló gazdasági társaságok az információszabadság szempontjából mindig is „renitens” szereplöknek minösültek. E vállalkozások a müködésükre és gazdálkodásukra vonatkozó adatok nyilvánosság elöl történö elvonása érdekében számos indokot felhoztak. Például az utóbbi időben mind gyakrabban hangoztatott érv az, hogy a piaci bevételek felhasználásával összefüggö információk nem tartoznak az átláthatósági követelmények hatálya alá. Ezen argumentum tulajdonképpen kettéválasztja közpénzt, illetve azokat a vagyonelemeket, amelyek forrása nem az állam vagy önkormányzat. Amig ugyanis az elöbbiekre vonatkozó adatok tekintetében a nyilvánosság a föszabály, addig utóbbi körbe tartozó információk - az érvelés elfogadása esetén - nem lennének megismerhetök az információszabadság keretében. Ebböl egyenesen az következik, hogy a köztulajdonban álló gazdasági társaságok tevékenységének létezne egy olyan szeglete, amelyre nem a nyilvánosság vagy annak törvényben meghatározott, legitim korlátai vonatkoznak. A transzparencia hiánya ugyanakkor visszaélésekre teremthet lehetöséget, amelynek megelözése érdekében mindenképpen célszerü megvizsgálni a fent emlitett érvelés helytállóságát.

\section{A közpénzek átláthatósága}

A modern állam számos funkciót tölt be, amelyek közül kiemelhető az allokációs (adóztatás), valamint a redisztribúciós funkció. Az adóztatási folyamat révén az adófizetők közösségétól pénzeszközöket von el, majd annak egy részét az újraelosztási folyamat során a társadalom számára visszajuttatja. Hagyományosan mindazon forrásközpénznek minősül, amely - közvetlenül vagy közvetve - az adófizetőktől folyik be az államháztartás egyes alrendszereibe, illetve amelyet onnan folyósítottak. ${ }^{2}$ A hatályos jog emellett

\footnotetext{
* DOI 10.21867/KjK/2018.2.1.

1 Dr. Révész Balázs, egyetemi docens SZTE, főosztályvezető NAIH; Dr. Buzás Péter, osztályvezető NAIH

${ }^{2}$ 2011. évi CXCV. törvény az államháztartásról (Áht.), 3. §.
} 
ebbe a körbe sorolja még az európai uniótól származó, illetve a nemzetközi megállapodások alapján nyújtott pénzeszközöket is. ${ }^{3}$

A közpénzek felhasználásának nyomon követése és ellenőrzése alapvető társadalmi elvárás egy demokratikus jogállamban. Az állam a redisztribúciós tevékenysége révén jelentős befolyást gyakorolhat olyanok - természetes vagy jogi személyek, illetve jogi személyiséggel nem rendelkező szervezetek helyzetére, akik vagy amelyek a vonatkozó döntések meghozatalában nem vehetnek részt. ${ }^{4}$ Ez tehát felételezi a különböző belső és külső kontrollmechanizmusok meglétét. Utóbbiak közé tartozik - többek között - a közérdekü és közérdekből nyilvános adatok megismeréséhez és terjesztéséhez füződő jog, vagyis az információszabadság.

Az Alaptörvény kimondja, hogy a közpénzekre vonatkozó gazdálkodással minden szervezet a nyilvánosság előtt köteles elszámolni. Ennek érdekében pedig a jogszabály a közpénzekre vonatkozó információkat közérdekủ adattá minősítette. ${ }^{5}$ Esetükben tehát főszabályként a nyilvánosság-elv érvényes, így azok megismerhetóségét minden közpénzekkel gazdálkodó szervezet köteles a vonatkozó törvényi előírások keretei között biztosítani.

$\mathrm{Az}$ átláthatósági követelmények azonban nem csak a közpénzeket elsődlegesen kezelő állami és önkormányzati szervekre vonatkoznak. A közpénzekre vonatkozó információk nyilvánosságának biztosítása ugyanis „,nem függvénye annak, hogy közérdekü adatot birtokló szervezet milyen szervezeti típusba tartozik, milyen tulajdonban van, milyen tevékenységet folytat". ${ }^{6}$ A döntő tényező, mely meghatározza a nyilvánosságát, az a juttatott vagyon forrása. Következésképpen az információszabadságból eredő kötelezettségek teljesítését már önmagában az megalapozza, hogy egy szerv vagy személy állami, önkormányzati forrásokból vagy ilyen szervektől származó közpénzt kezel.

A köztulajdonban álló gazdasági társaságok pénzeszközeinek általában csak egy részét képezik a közpénzek. Az állami vagy önkormányzati források mellett ugyanis e vállalkozások számos esetben profitorientált tevékenységeket is folytatnak, amelynek célja a piacról származó pénzügyi források növelése. Amennyiben tehát elfogadjuk a bevezetésben említett érvelést, úgy arra kellene következtetnünk, hogy az információszabadság e cégek esetében kizárólag a közpénzek, de nem a piaci bevételek felhasználásának ellenőrzését teszi lehetővé. Azaz a piaci profittal való gazdálkodásra vonatkozó adatok megismerhetőségét nem kötelesek biztosítani.

\footnotetext{
3 2007. évi CLXXXI. törvény a közpénzekből nyújtott támogatások átláthatóságáról (Knyt.) 1. § (1) bekezdés.

4 Pétervári Kinga (2004): Közpénzek - magánpénzek, avagy a számvevöszéki ellenörzés alkotmányjogi problémái. Budapest: Gondolat, 45-46. old.

${ }^{5}$ Alaptörvény 39. cikk (2) bekezdés.

${ }^{6}$ 3026/2015. (II. 9.) AB határozat, 35. pont.
} 
A fenti gondolatmenet ugyanakkor figyelmen kívül hagyja, hogy az információszabadság nem csak a közpénzek felhasználásának ellenőrzését teszi lehetővé. Az átláthatóság és a közélet tisztaságának - Nemzeti Hitvallásban deklarált - elvei „általában véve a közfeladatok ellátásával összefüggő adatok kezelése szempontjából is irányadó[k]". Azaz minden, állami vagy helyi önkormányzati feladatot, valamint jogszabályban meghatározott egyéb közfeladatot ellátó szerv vagy személy köteles a tevékenységére vonatkozó vagy közfeladatának ellátásával összefüggésben keletkezett közérdekü és közérdekből nyilvános adat megismerhetőségét biztosítani. ${ }^{7}$ Amennyiben tehát a köztulajdonban álló gazdasági társaságok közfeladatot ellátó szerveknek minősülnek, a transzparencia követelménye - törvényes korlátok között - a közpénzek felhasználásán túl egyéb területekre is kiterjed.

\section{Köztulajdonban álló gazdasági társaság, mint közfeladatot ellátó szerv}

A köztulajdonban álló gazdasági társaságok sokáig oly módon próbálták meg mentesíteni magukat az információszabadságból eredő kötelezettségek teljesítésétől, hogy tagadták a közfeladat-ellátói szerepüket. Érvelésük alapja az volt, hogy jogszabályban meghatározott feladatkör hiányában nem kötelesek biztosítani a nyilvánosságot a kezelésükben lévő adatok tekintetében. Mára azonban - a hatályos jogszabályokon alapuló - jogalkalmazói gyakorlat egységes abban, hogy az említett vállalkozások közfeladat-ellátói minőségét több szempont is megalapozza.

Ezek az entitások egyrészt állami és önkormányzati tevékenységek, feladatok széles körét ellátják. Egyes esetekben maguk a jogszabályok nevesítik azokat a konkrét gazdasági társaságokat, amelyek kiemelten közfeladatokat látnak el. Példaként említhető a Magyar Nemzeti Bank, továbbá az Államadósság Kezelő Központ. Máskor piacorientált társaságok - mint a Magyar Export-Import Bank és a Magyar Exporthitel Biztosító vonatkozásában tartalmaznak ilyen rendelkezéseket. Végezetül bizonyos, csak a jogi személyek meghatározott csoportja által végezhető tevékenységeket is szabályozhat a jogalkotó. Ebbe a körbe tartoznak - többek között - az egyes közmüszolgáltató cégek. ${ }^{8}$

Másrészt az állami vagy önkormányzati tulajdonban álló gazdasági társaságok rendelkezésére álló - anyagi és egyéb - eszközök a nemzeti vagyon körébe tartoznak. E vállalkozások így annak kezelésével, felhasználásával összefüggésben hoznak döntéseket. Márpedig a nemzeti vagyon alapvetö rendeltetése kizárólag közfeladatok ellátásának biztosítása lehet. ${ }^{9}$ Az állami

\footnotetext{
7 2011. évi CXII. törvény az információs önrendelkezési jogról és az információszabadságról (Infotv.) 26. § (1) bekezdés

${ }^{8}$ Infotv. 26. § (3) bekezdés

${ }^{9}$ 2011. évi CXCVI. törvény a nemzeti vagyonról (Nvtv.) 7. § (1) bekezdés.
} 
vagyonnal gazdálkodó szervek pedig közfeladatot ellátó szerveknek minősülnek.

A fentiekből következően egy állami vagy önkormányzati tulajdonban álló gazdasági társaság ,jogszabályban meghatározott egyéb közfeladatot ellátó szervként az általa kezelt közérdekű [és közérdekből nyilvános] adatok megismerhetővé tételére köteles". Márpedig a közérdekü adatok körébe minden olyan információ beletartozik, amely az adott közfeladatot ellátó szerv tevékenységére vonatkozik vagy közfeladatának ellátásával összefüggésben keletkezett, „különösen a hatáskörre, illetékességre, szervezeti felépítésre, szakmai tevékenységre, annak eredményességére is kiterjedő értékelésére, a birtokolt adatfajtákra és a múködést szabályozó jogszabályokra, valamint a gazdálkodásra, a megkötött szerződésekre vonatkozó adat". ${ }^{10}$ A vonatkozó jogszabályok ugyanakkor nem tartalmaznak kivételt közfeladatot ellátó szerv „gazdálkodása" tekintetében, így ebbe a körbe mind az állami és önkormányzati, mind pedig a piaci forrásból szerzett pénzeszközök beletartoznak.

$$
\text { **** }
$$

A köztulajdonban álló gazdasági társaságok számos, a nemzetgazdaság szempontjából fontos feladatot elláthatnak. Ehhez egyrészt a tulajdonos - állam vagy önkormányzat - biztosít forrásokat, másrészt kiegészül a vállalkozás gazdasági tevékenységéből eredő profittal. Utóbbi azonban nem jelenti azt, hogy a rájuk vonatkozó adatok ne lennének nyilvánosak. Amíg ugyanis a közpénzek felhasználásának átláthatósága többszörösen is biztosított, addig a vállalkozási tevékenységből eredő profit esetén e szervezetek - mint közfeladatot ellátó szervek - a gazdálkodásuk körében kötelesek a közvélemény elött elszámolni. Az információszabadság érvényesülésének szempontjából tehát irreleváns az, hogy a köztulajdonban álló gazdasági társaság milyen forrásból eredő pénzt használ fel: mind a közpénzekkel, mind pedig a piaci profittal való gazdálkodással kapcsolatos információk közérdekü adatoknak minősülnek.

\section{Források jegyzéke:}

- Pétervári Kinga (2004): Közpénzek - magánpénzek, avagy a számvevöszéki ellenőrzés alkotmányjogi problémái. Budapest: Gondolat, 45-46. old.

- 2007. évi CLXXXI. törvény a közpénzekböl nyújtott támogatások átláthatóságáról

- 2011. évi CXCV. törvény az államháztartásról

${ }^{10}$ Infotv. 3. § 5. pont 
- 2011. évi CXCVI. törvény a nemzeti vagyonról

- 2011. évi CXII. törvény az információs önrendelkezési jogról és az információszabadságról

- 3026/2015. (II. 9.) AB határozat

- Magyarország Alaptörvénye 